\title{
KEMAMPUAN BERBICARA SISWA MTS HIDAYATUL MUSTAQIM BALIKPAPAN MELALUI KEGIATAN MENJADI PEMBAWA ACARA
}

\author{
Duwi Rahayu', Maryatin ${ }^{2}$, Retnowaty ${ }^{3}$ \\ Universitas Balikpapan ${ }^{1}$, Universitas Balikpapan ${ }^{2}$, Universitas Balikpapan ${ }^{3}$ \\ pos-el: DuwiRahayu94@gmail.com¹, Maryatin@uniba-bpn.ac.id², Retnowaty@uniba-bpn.ac.id ${ }^{3}$
}

\begin{abstract}
ABSTRAK
Penelitian ini bertujuan untuk mengetahui kemampuan berbicara siswa kelas VIII MTs Hidayatul Mustaqim Balikpapan. Penelitian ini merupakan penelitian kualitatif yang bermaksud untuk memahami fenomena tentang apa yang dialami oleh subjek penelitian dengan cara mendeskripsikan dalam bentuk kata-kata dan bahasa. Subjek pada penelitian ini yaitu siswa kelas VIII MTs Hidayatul Mustaqim Balikpapan berjumlah 41 siswa. Data diambil untuk mengetahui kemampuan berbicara siswa kelas VIII dengan menggunakan observasi, penilaian tes, dan wawancara. Teknik analisis data yang diguanakan adalah deskriptif yang bertujuan untuk memberikan gambaran realita yang ada tentang kemampuan berbicara siswa kelas VIII MTs Hidayatul Mustaqim Balikpapan. Hasil penelitian ini menunjukkan bahwa kemampuan berbicara siswa kelas VIII MTs Hidayatul Mustaqim Balikpapan termasuk ke dalam kategori baik yaitu sebanyak 20 siswa dari 41 siswa yang terdiri dari 21 siswa perempuan dan 20 siswa laki-laki, atau sebesar $48.78 \%$. Kemampuan ini sudah baik untuk ukuran siswa kelas VIII MTs yang sedang mengalami perubahan masa-masa remaja. Jika ditingkatkan lagi dengan pembelajaran bahasa Indonesia yang rutin dan terarah, maka kemampuan berbicara siswa akan meningkat dan masuk kategori sangat baik.
\end{abstract}

Kata kunci : Kemampuan Berbicara, Siswa MTS

\section{ABSTRACT}

This study aims to determine the ability to speak students of class VIII MTs Hidayatul Mustaqim Balikpapan. This study is a qualitative research that intends to understand the phenomenon of what is experienced by the subject of research by way of describing in the form of words and language. Subjects in this study are students of class VIII MTs Hidayatul Mustaqim Balikpapan amounted to 41 students. Data was taken to know the ability of speaking of class VIII students by using observation, assessment of test, and interview. Data analysis technique used is descriptive that aims to provide an overview of the existing reality of the ability to speak students of class VIII MTs Hidayatul Mustaqim Balikpapan. The results of this study indicate that the ability to speak students of grade VIII MTs Hidayatul Mustaqim Balikpapan included into either category as many as 20 students from 41 students consisting of 21 female students and 20 male students, or equal to $48.78 \%$. This ability is good for the size of the VIII class of MTs students who are undergoing changes in adolescence. If it is upgraded again with regular and targeted Indonesian language learning, students' speaking skills will increase and be categorized very well.

Keywords: Speaking skill. MTS Students

\section{PENDAHULUAN}

Berbahasa merupakan suatu yang sangat penting untuk dikuasai setiap orang. Setiap orang saling berhubungan dengan orang lain dengan cara berkomunikasi. kemampuan berbahasa adalah salah satu unsur penting yang menentukan kesuksesan dalam berkomunikasi.
Kemampuan berbahasa mencakup: kemampuan menyimak, kemampuan berbicara, kemampuan menulis, dan kemampuan membaca. Keempat kemampuan tersebut saling terkait antara yang satu dengan yang lain (Saddhono (Mongi, 2015)). 
Kemampuan berbicara merupakan salah satu kemampuan berbahasa yang harus dikuasai siswa karena kompetensi kemampuan berbicara adalah salah satu komponen dalam tujuan pembelajaran bahasa Indonesia. Pembelajaran kemampuan berbicara perlu mendapat perhatian agar siswa dapat berkomunikasi dengan baik. Siswa yang memiliki kemampuan berbicara akan lebih mudah dalam menyampaikan ide atau gagasan.

Menurut Arsjad dan Mukti (1993:17) berbicara adalah kemampuan dalam mengungkapkan bunyi-bunyi artikulasi atau mengucapkan kata-kata untuk mengekspresikan, menyatakan, menyampaikan pikiran, gagasan, dan perasaan. Pendengar menerima informasi melalui rangkaian nada, tekanan, dan penempatan persendian. Jika komunikasi berlangsung secara tatap muka, ditambah lagi dengan gerak tangan dan air muka (mimik) pembicara.

Kemampuan berbicara tidak dapat secara langsung dimiliki oleh semua orang, sebagian besar memerlukan latihan atau pengalaman berbicara. Bicara merupakan sesuatu yang khas pada manusia karena bicara adalah salah satu sistem komunikasi di mana seseorang mengutarakan pendapat dan perasaan hati dan mengerti maksud seseorang melalui pendengar (Sidiarto(Musaba, 2012:4)).

Pentingnya kemampuan berbicara atau bercerita dalam komunikasi juga diungkapkan oleh Supriyadi (Leksono, 2013: 3) yang mengatakan bahwa apabila seseorang memiliki keterampilan berbicara yang baik, dia akan memperoleh keuntungan sosial maupun profesional. Keuntungan sosial berkaitan dengan kegiatan interaksi sosial antar individu. Sedangkan, keuntungan profesional diperoleh sewaktu menggunakan bahasa dalam berbicara untuk membuat pertanyaan-pertanyaan, menyampaikan fakta-fakta dan pengetahuan, menjelaskan dan mendeskripsikan.

Keuntungan profesional dari beberapa profesi yang membutuhkan keahlian dalam kemampuan berbicara, salah satu diantaranya yaitu seorang guru yang sehari-harinya banyak berhadapan dengan muridnya. Interaksi antara guru dengan murid lebih banyak dilakukan dengan berbicara. Guru yang berkualitas hendaknya mampu berbicara di depan peserta didiknya dengan baik, karena seorang guru hendaknya menjadi contoh atau inspirasi bagi muridnya, seperti cara berbicaranya atau gaya berbicaranya ketika guru tersebut berbicara di depan orang lain.

Guru yang berkualitas hendaknya mampu menciptakan proses belajar yang baik. Proses belajar yang baik akan menghasilkan siswa dengan kemampuan yang baik pula. Selama ini proses pembelajaran di MTs Hidayatul Mustaqim Balikpapan khususnya pada mata pelajaran Bahasa Indonesia masih sangat kurang karena proses pembelajaran masih berfokus pada guru yang menyebabkan siswa bosan dan kurang aktif dalam mengikuti pembelajaran, lebih sering memilih diam ketika diberi kesempatan untuk bertanya, tidak bersedia mengemukakan pendapat (usul, saran atau tanggapan) secara lisan atau menjawab pertanyaan. Kebanyakan dari mereka lebih memilih diam daripada berbicara karena berbagai alasan, misalnya takut salah, malu ditertawakan oleh teman atau memang tidak ada keberanian untuk mengungkapkan walau sebenarnya siswa mengetahuinya.

Berdasarkan wawancara terhadap guru kelas VIII MTs Hidayatul Mustaqim Balikpapan bahwa kemampuan berbicara mereka masuk ke dalam kategori cukup baik, namun jika mereka mau bersungguhsungguh ketika mereka berbicara di depan orang lain dan adanya tekanan terhadap penilaian maka kemampuan berbicara mereka akan mengalami peningkatan menjadi baik.

Berdasarkan permasalahan tersebut, peneliti tertarik untuk melakukan penelitian yang berjudul "Kemampuan 
Berbicara Siswa MTs Hidayatul Mustaqim Balikpapan Tahun Ajaran 2016/2017”.

\section{Kemampuan Berbahasa}

$$
\text { Menurut Musaba }
$$

Kemampuan berbahasa meliputi empat macam. Keempat macam kemampuan berbahasa tersebut adalah sebagai berikut: (1) kemampuan mendengarkan atau menyimak, (2) kemampuan berbicara, (3) kemampuan membaca, dan (4) kemampuan menulis. Keempat kemampuan berbahasa ini sangat penting dikuasai oleh seseorang. Seseorang dikatakan mampu mendengarkan jika ia dapat menerima dengan benar dan cepat terhadap informasinya yang didengarnya. Seseorang dikatakan mampu berbicara jika ia dapat mengemukakan segala ide serta perasaannya dengan jelas kepada orang lain. Seseorang dikatakan mampu membaca jika ia dapat menangkap atau menerima dengan benar dan cepat dari apa yang dibaca melalui tulisan. Seseorang dikatakan mampu menulis jika ia dapat mengemukakan ide atau buah pikirannya serta perasaannya melalui tulisan.

\section{Pengertian Berbicara}

Menurut Tarigan (2008:16) berbicara adalah kemampuan mengucapkan bunyibunyi artikulasi atau kata-kata untuk mengekspresikan, menyatakan atau menyampaikan pikiran, gagasan, dan perasaan. Sebagai perluasan dari batasan ini dapat kita katakan bahwa berbicara merupakan suatu sistem tanda-tanda yang dapat didengar (audible) dan yang kelihatan (visible) yang memanfaatkan sejumlah otot dan jaringan otot tubuh manusia demi maksud dan tujuan gagasangagasan atau ide-ide yang dikombinasikan. Berbicara merupakan suatu bentuk perilaku manusia yang memanfaatkan faktor-faktor fisik, psikologis, neurologis, semantik, dan linguistik sedemikian ekstensif, secara luas sehingga dapat dianggap sebagai alat manusia yang paling penting bagi kontrol sosial.
Menurut Sidiarto (Musaba, 2012:4) bicara merupakan sesuatu yang khas pada manusia karena bicara adalah satu sistem komunikasi di mana seseorang mengutarakan pendapat dan perasaan hatinya yang dapat dimengerti maksud dan tujuannya oleh seseorang melalui pendengaran. Kemampuan berbicara seseorang perlu terus ditingkatkan agar kualitas berbicaranya semakin baik.

Menurut Mulgrave (Tarigan, 2008:16) berbicara adalah suatu alat untuk mengkomunikasikan gagasan-gagasan yang disusun serta dikembangkan sesuai dengan kebutuhan-kebutuhan sang pendengar atau penyimak. Berbicara merupakan instrument yang mengungkapkan kepada penyimak hampir-hampir secara langsung apakah sang pembicara memahami atau tidak, baik bahan pembicaraannya maupun para penyimaknya; apakah dia bersikap tenang serta dapat menyesuaikan diri atau tidak, pada saat dia mengkomunikasikan gagasan-gagasannya; dan apakah dia waspada serta antusias atau tidak.

Untuk dapat menjadi pembicara yang baik, seorang pembicara selain harus memberikan kesan bahwa ia menguasai masalah yang dibicarakan, si pembicarajuga harus memperlihatkan keberanian dan kegairahan. Pembicara harus berbicara dengan jelas dan tepat. Faktor yang harus diperhatikan oleh si pembicara untuk keefektifan berbicara, yaitu faktor kebahasaan dan faktor nonkebahasaan. Arsjad dan Mukti (1993:17-22), mengemukakan faktor kebahasaan dan faktor nonkebahasaan, yaitu:

\section{Faktor-Faktor Kebahasaan}

a. Ketepatan Ucapan

Seorang pembicara harus membiasakan diri mengucapkan bunyibunyi bahasa secara tepat. Pengucapan bunyi bahasa yang kurang tepat, dapat mengalihkan perhatian pendengar. Setiap penutur sangat dipengaruhi oleh bahasa 
ibunya. Misalnya, pengucapan $e$ yang kurang tepat, bébas diucapkan bebas.

Demikian juga halnya dengan pengucapan tiap suku kata. Sering kitadengar tidak jarang orang mengucapkan kata-kata yang tidak jelas suku katanya. Suku kata yang diucapkan berdempet, kadang-kadang hilang bunyibunyi tertentu. Misalnya pemrintah atau pemerintah, sudagar atau saudagar, dan lain-lain.

b. Penempatan Tekanan, Nada, Sendi, dan Durasi yang Sesuai

Penempatan tekanan, nada, sendi, dan durasi akan menjadi daya tarik tersendiri dalam berbicara, bahkan kadang-kadang merupakan faktor penentu yang menyebabkan masalah pembicaraan menjadi menarik. Penempatan tekanan suara yang biasanya jatuh pada suku kata terakhir atau suku kata kedua dari belakang, kemudian kita tempatkan pada suku kata pertama. Misalnya kata pemberani dan kesempatan, kita beri tekanan pada pem-, $k e-$, $\quad$ tentu kedengarannya janggal, sehingga pokok pembicaraan atau pesan yang disampaikan kurang diperhatikan.

c. Pilihan Kata (Diksi)

Pilihan kata hendaknya tepat, jelas, dan bervariasi. Pilihn kata jelas maksudnya mudah dimengerti oleh para pendengar yang menjadi sasaran. Pemilihan kata harus disesuaikan dengan pokok pembicaraan dan pendengarnya.

d. Ketepatan Sasaran Pembicaraan

Ketepatan sasaran pembicaraan menyangkut penyusunan kalimat efektif, kalimat yang mengenai sasaran, sehingga mampu menimbulkan pengaruh, meninggalkan kesan, atau menimbulkan akibat.

Kalimat yang efektif mempunyai ciriciri keutuhan, perpautan, pemusatan perhatian, dan kehematan. Ciri keutuhan akan terlihat jika setiap kata betul-betul merupakan bagian yang padu dari sebuah kalimat. Keutuhan kalimat akan rusak karena ketiadaan subjek atau adanya kerancuan. Perpautan, bertalian dengan hubungan antara unsur-unsur kalimat, misalnya antara kata dengan kata, frase dengan frase dalam sebuah kalimat. Kalimat efektif jugaharus hemat dalam pemakaian kata, sehingga tidak ada katakata yang mubazir artinya tidak berfungsi sehingga dapat disingkirkan.

\section{Faktor-Faktor Nonkebahasaan}

a. Sikap yang Wajar, Tenang, dan Tidak Kaku

Pembicara yang tidak tenang, lesu, dan kaku tentulah akan memberikan kesan pertama yang kurang menarik. Sikap yang wajar sang pembicara sudah dapat menunjukkan otoritas dan integritas dirinya. Sikap ini sangat banyak ditentukan oleh situasi, tempat, dan penguasaan materi. Penguasaan materi yang baik, setidaknya akan menghilangkan kegugupan. sikap ini sebaiknya dalam latihan yang ditanamkan lebih awal, karena sikap ini merupakan modal utama untuk kesuksesan dalam berbicara.

b. Pandangan Harus Diarahkan kepada Lawan Bicara

Sikap ini melibatkan pada semua pendengar. Pandangan yang hanya tertuju pada satu arah, akan menyebabkan pendengar merasa kurang diperhatikan. Banyak pembicara ketika berbicara tidak memperhatikan pendengar, tetapi melihat ke atas, ke samping, atau menunduk. Pembicara seharusnya mengusahakan agar pendengar merasa terlibat dan diperhatikan.

c. Kesediaan Menghargai Pendapat Orang Lain

Seorang pembicara hendaknya memiliki sikap terbuka dalam arti mau menerima pendapat orang lain dan bersedia menerima kritik, bersediamengubah pendapatnya jika ternyata memang keliru. Pembicara tidak harus begitu saja mengikuti pendapat orang lain dan mengubah pendapatnya, tetapi ia juga harus mampu mempertahankan pendapatnya dan meyakinkan orang lain, jika pendapatnya 
itu mengandung argumen-argumen yang kuat, dan betul-betul diyakini kebenarannya. 17

d. Gerak-Gerik dan Mimik yang Tepat

Gerak- gerik dan mimik yang tepat dapat pula menunjang keefektifan berbicara, selain itu dapat menghidupkan komunikasi, artinya tidak kaku. Gerakgerik yang berlebihan juga akan mengganggu keefektifan berbicara. Perhatian pendengar akan terarah pada gerak-gerik dan mimik yang berlebihan ini, sehingga pesan kurang dipahami.

\section{e. Kenyaringan suara}

Tingkat kenyaringan ini tentu disesuaikan dengan situasi, tempat, jumlah pendengar, dan akustik. Dengan kenyaringan suara, pendengar dapat mendengarkan dengan jelas isi pembicaraan.

\section{f. Kelancaran}

Seorang pembicara yang lancar berbicaranya akan memudahkan pendengar menangkap isi pembicaraannya. Sebaliknya pembicara yang terlalu cepat berbicara juga akan menyulitkan pendengar menangkap pokok pembicaraan. Oleh karena itu, pembicara diharapkan dapat mengatur tempo katakata atau kalimat.

\section{g. Relevansi/Penalaran}

Gagasan demi gagasan haruslah berhubungan dengan logis, hal ini berarti hubungan bagian-bagian dalam kalimat, hubungan kalimat dengan kalimat harus logis dan berhubungan dengan pokok pembicaraan.

\section{h. Penguasaan Topik}

Penguasaan topik yang baik akan menumbuhkan keberanian dan kelancaran. Oleh karena itu, penguasaan topik ini sangat penting, bahkan merupakan faktor utama dalam berbicara.

\section{METODE PENELITIAN}

Jenis penelitian ini merupakan penelitian kualitatif. Menurut Moleong (2014:6) penelitian kualitatif adalah penelitian yang bermaksud untuk memahami fenomena tentang apa yang dialami oleh subjek penelitian misalnya perilaku, persepsi, motivasi, tindakan, dan lain-lain secara holistik, dan dengan cara deskripsi dalam bentuk kata-kata dan bahasa, pada suatu konteks khusus yang alamiah dan dengan memanfaatkan berbagai metode alamiah.

Penelitian ini dilaksanakan di MTs (Madrasah Tsanawiyah) Hidayatul Mustaqim yang berlokasi di Jalan Pasar Gunung Tembak RT 17 Kelurahan Teritip, Kecamatan Balikpapan Timur, Provinsi Kalimantan Timur. Adapun waktu penelitian ini dilakukan pada bulan MaretJuli semester II, tahun ajaran 2016/2017.

Subjek pada penelitian ini yaitu siswa kelas VIII MTs Hidayatul Mustaqim Balikpapan tahun ajaran 2016/2017 berjumlah 41 siswa, 20 siswa laki-laki dan 21 siswa perempuan, sedangkan objek pada penelitian ini adalah kemampuan berbicara siswa kelas VIII MTs Hidayatul Mustaqim Balikpapan.

Instrumen pada penelitian ini adalah peneliti sendiri. Menurut Moleong (2014:9) peneliti sendiri merupakan alat pengumpul data utama. Peneliti juga dibantu dengan lembar observasi, lembar penilaian tes kemampuan berbicara, serta pedoman wawancara. Lembar observasi digunakan untuk mengamati kemampuan berbicara siswa. Pada tahap observasi ini peneliti menggunakan tanda check list pada lembar observasi. Lembar observasi ini dimodifikasi dari penilaian milik Arsjad dan Mukti (1993:17). Penilaian tersebut mencakup faktor kebahasaan dan nonkebahasaan.

Lembar penilaian tes, digunakan untuk mengukur kemampuan berbicara siswa kelas VIII. Pedoman wawancara digunakan untuk mengetahui hal-hal dari responden yang lebih mendalam dan jumlah respondennya sedikit/kecil. Pertanyaan diberikan terhadap guru mata pelajaran bahasa Indonesia kelas VIII yang mengetahui keadaan yang terjadi pada siswanya. 


\section{HASIL DAN PEMBAHASAN}

\section{a. Hasil Penelitian}

Hasil analisis terhadap kemampuan berbicara siswa kelas VIII MTS Hidayatul Mustaqim Balikpapan melalui tes menjadi pembawa acara dengan pengkategorian menjadi 4 kategori yaitu sangat baik, baik, cukup baik, dan kurang menghasilkan nilai tertinggi 40 dan nilai terendah 16 . Hasil penelitian dapat dilihat pada tabel berikut:

Tabel 1 Kemampuan Berbicara Siswa

\begin{tabular}{|c|c|c|c|c|}
\hline No & Nilai & Kategori & Jumlah & Presentase \\
\hline 1 & $37-48$ & Sangat Baik & 3 & $7.3 \%$ \\
\hline 2 & $25-36$ & Baik & 20 & $48.78 \%$ \\
\hline 3 & $13-24$ & Cukup Baik & 12 & $29.26 \%$ \\
\hline 4 & $\leq 12$ & Kurang & 0 & $0 \%$ \\
\hline
\end{tabular}

Dari tabel tersebut menunjukkan bahwa kemampuan berbicara siswa kelas VIII MTs Hidayatul Mustaqim Balikpapan yang termasuk ke dalam kategori sangat baik sebanyak 3 siswa atau sebesar 7.3\%, kategori baik sebanyak 20 siswa atau sebesar $48.78 \%$, kategori cukup baik sebanyak 12 siswa atau sebesar $29.26 \%$, kategori kurang sebanyak 0 siswa atau sebesar $0 \%$.

Setelah hasil tes kemampuan berbicara siswa kelas VIII diketahui, berikut penyajian deskripsi data pada masing-masing aspek tes:

a) Faktor Kebahasaan

Hasil tes berbicara siswa kelas VIII MTs Hidayatul Mustaqim Balikpapan adalah sebagai berikut:
Tabel 2 Faktor Kebahasaan Siswa

\begin{tabular}{|c|c|c|c|c|}
\hline No & Nilai & Kategori & $\begin{array}{c}\text { Jumlah } \\
\text { Siswa }\end{array}$ & Presentase \\
\hline 1 & $13-16$ & Sangat Baik & 2 & $4.8 \%$ \\
\hline 2 & $9-12$ & Baik & 23 & $56.09 \%$ \\
\hline 3 & $5-8$ & Cukup Baik & 10 & $24.39 \%$ \\
\hline 4 & $<4$ & Kurang & 0 & $0 \%$ \\
\hline
\end{tabular}

Dari tabel di atas, dapat dilihat dari hasil tes aspek kebahasaan yang termasuk ke dalam kategori sangat baik sebanyak 2 siswa atau sebesar $4.8 \%$, kategori baik sebanyak 23 siswa atau sebesar $56.09 \%$, kategori cukup baik sebanyak 10 siswa atau sebesar $24.39 \%$, kategori kurang sebanyak 0 siswa atau $0 \%$.

b) Faktor Nonkebahasaan

Hasil tes nonkebahasaan siswa kelas VIII MTs Hidayatul Mustaqim Balikpapan adalah sebagai berikut:

Tabel 3 Faktor Nonkebahasaan Siswa

\begin{tabular}{|c|c|c|c|c|}
\hline No & Nilai & Kategori & $\begin{array}{c}\text { Jumlah } \\
\text { Siswa }\end{array}$ & Presentase \\
\hline 1 & $25-32$ & Sangat Baik & 4 & $9.7 \%$ \\
\hline 2 & $17-24$ & Baik & 15 & $36.58 \%$ \\
\hline 3 & $9-16$ & Cukup Baik & 16 & $39.02 \%$ \\
\hline 4 & $<8$ & Kurang & 0 & $0 \%$ \\
\hline
\end{tabular}

Dari tabel tes di atas, bahwa hasil tes nonkebahasaan yang termasuk ke dalam kategori sangat baik sebanyak 4 siswa atau 9.7\%, kategori baik sebanyak 15 siswa atau $36.58 \%$, kategori cukup baik 16 siswa atau $39.02 \%$, dan kategori kurang sebanyak 0 siswa atau $0 \%$.

\section{b. Pembahasan}

Kemampuan berbicara diartikan sebagai kemampuan komunikasi dalam mengucapkan bunyi-buyi artikulasi atau kata-kata untuk mengekspresikan, mengemukakan pendapat, dan perasaan, kemudian dapat dikembangkan sesuai 
dengan kebutuhan-kebutuhan sang pendengar atau penyimak. Seseorang akan dikatakan mampu berbicara jika memiliki keberanian dan kemampuan untuk menyampaikan apa yang menjadi gagasan, pikiran, dan pendapatnya, dan dapat dipahami oleh pendengar atau penyimak.

Berbicara yang baik dan benar akan membantu proses pendidikan untuk mencapai tujuannya, maka kehadiran pembelajaran berbicara menentukan keberhasilan pendidikan. Pembelajaran berbicara memudahkan siswa untuk dapat memahami tujuan berbicara. Berbicara tidak bisa dilepas begitu saja karena merupakan bagian dari kebutuhan hidup manusia yang tidak dapat dipisahkan.

Berdasarkan analisis hasil tes kemampuan berbicara siswa kelas VIII MTs Hidayatul Mustaqim Balikpapan menunjukkan bahwa yang termasuk ke dalam kategori sangat baik sebanyak 3 siswa atau sebesar $7.3 \%$, kategori baik sebanyak 20 siswa atau sebesar $48.78 \%$, kategori cukup baik sebanyak 12 siswa atau sebanyak 29.26\%, kategori kurang sebanyak 0 siswa atau $0 \%$. Jika dilihat berdasarkan analisis hasil tes kemampuan berbicara siswa kelas VIII MTs Hidayatul Mustaqim Balikpapan pada masingmasing aspek tes yaitu, faktor kebahasaan dan faktor nonkebahasaan, hasil tes faktor kebahasaan yang termasuk ke dalam kategori sangat baik sebanyak 2 siswa atau sebesar $4.8 \%$, kategori baik sebanyak 23 siswa atau sebesar $56.09 \%$, kategori cukup baik sebanyak 10 siswa atau sebesar $24.39 \%$, kategori kurang sebanyak 0 siswa atau $0 \%$. Sedangkan hasil tes faktor nonkebahasaan yang termasuk ke dalam kategori sangat baik sebanyak 4 siswa atau sebesar 9.7\%, kategori baik sebanyak 15 siswa atau sebesar 36.58, kategori cukup baik 16 siswa atau sebesar $39.02 \%$, dan kategori kurang sebanyak 0 siswa atau sebesar $0 \%$.

Dengan melihat hasil penelitian tes di atas, maka tingkat kemampuan berbicara siswa kelas VIII termasuk ke dalam kategori baik yaitu sebanyak 20 siswa dari
41 siswa kelas VIII, atau sebesar $48.78 \%$. Pada saat observasi awal, siswa lebih banyak tidak melaksanakan apa yang menjadi penilaian, karena guru belum memberikan contoh bagaimana menjadi pembawa acara yang baik. Namun setelah guru memberikan contoh bagaimana menjadi pembawa acara yang baik, terdapat sedikit peningkatan daripada saat observasi awal. Faktor-faktor pendukung para siswa mendapatkan penilaian menjadi baik yaitu dari faktor kebahasaan, jika dilihat dari faktor nonkebahasan, kemampuan berbicara siswa termasuk kurang karena walaupun sudah diberikan contoh oleh gurunya bagaimana menempatkan gerak-gerik mimik yang tepat, sikap yang wajar, tenang dan tidak kaku serta pandangan harus diarahkan kepada lawan bicara, akan tetapi mereka belum menerapkan itu semua pada saat pengambilan nilai kemampuan berbicara mereka. Mereka masih terlihat jelas bahwa kepercayaan diri mereka masih sangat kurang, akan tetapi hal ini sudah baik untuk ukuran siswa kelas VIII MTs yang sedang mengalami perubahan masa-masa remaja. Jika ditingkatkan lagi dengan pembelajaran bahasa Indonesia yang rutin dan terarah, maka kemampuan berbicara siswa akan meningkat dan masuk kategori sangat baik.

Berdasarkan hasil wawancara yang dilakukan terhadap guru mata pelajaran Bahasa Indonesia kelas VIII MTs Hidayatul Mustaqim Balikpapan, perasaan malu dan kurang percaya diri merupakan hal yang paling mempengaruhi kemampuan berbicara siswa. Oleh karena itu, hal tersebut sebagai salah satu kendala bagi guru dalam meningkatkan kemampuan berbicara mereka.

Berdasarkan asumsi peneliti, jika siswa-siswi mau berusaha dengan sungguh-sungguh ketika mereka berbicara di depan khalayak atau teman-temannya, maka mereka akan mendapatkan hasil yang baik walaupun masih terdapat kekurangan-kekurangan yang dapat diperbaiki pada saat proses pembelajaran 
berlangsung agar lebih meningkatkan kemampuan berbicara mereka pada masa mendatang.

\section{KESIMPULAN}

Proses pembelajaran sangat dipengaruhi oleh komunikasi antara guru dan siswanya, siswa yang satu dengan siswa yang lain. Jika siswa mempunyai kemampuan berbicara yang baik, maka akan terjadi proses timbal balik dalam proses pembelajaran. Kegiatan tanya jawab akan sangat membantu siswa dalam mempelajari apa yang belum mereka ketahui dan bagaimana cara penanganannya. Jika komunikasi antara siswa dengan guru baik, maka hal ini akan memberikan kemudahan bagi guru maupun siswa untuk lebih menjalin keakraban guna tercapainya proses belajar-mengajar yang baik.

\section{DAFTAR PUSTAKA}

Ahmad, Hendra. (2013). Kemampuan Siswa Berbicara dengan Metode Diskusi di Kelas IV SDN No.88 Kota Tengah Kota Gorontalo. Jurnal, Universitas Negeri Gorontalo, Gorontalo. Diakses pada tanggal 04 April 2017, dari

http://kim.ung.ac.id.

Arsjad, Maidar G \& Mukti U.S. (1993). Pembinaan Kemampuan

Berbicara Bahasa Indonesia. Jakarta: Erlangga.

FKIP Universitas Balikpapan. (2013). Panduan Penulisan Tugas Akhir. Yogyakarta: Lilin Persada Press.

Leksono, Gilar Pandu. (2013) Kemampuan Berbicara Siswa Kelas Tinggi di SD Negeri 1 Kedunglegok, Kecamatan Kemangkon, Kabupaten Purbalingga. Skripsi, Universitas Yogyakarta, Yogyakarta.
Diakses pada tanggal 08 Februari 2017, dari http://eprints.uny.ac.id.

Moleong, Lexy J. (2014). Metodologi Penelitian Kualitatif (edisi revisi). Bandung: PT Remaja Rosdakarya

Mongi, Jeanne. (2015). Peningkatan

Keaktifan dan Kemampuan

Berbicara dengan

Menggunakan Metode

Pembelajaran Kooperatif

Model Jigsaw Pada Siswa

Kelas VIII-B SMP Kristen GPIB

Balikpapan. Skripsi, tidak diterbikan, Universitas Balikpapan, Balikpapan.

Musaba, Zulkifli. (2012). Terampil Berbicara Teori dan Pedoman Penerapannya. Yogyakarta: CV. Aswaja Pressindo.

Sugiyono. (2015). Metode Penelitian Pendidikan Pendekatan Kuantitatif Kualitatif, dan R\&D. Bandung: CV. Alfabeta.

Tarigan, Henry Guntur. (2008). Berbicara Sebagai Suatu Keterampilan Berbahasa. Bandung: Angkasa. 